\title{
EXPRESSED EMOTION TOWARDS INDIVIDUALS WITH MENTAL AND PHYSICAL HEALTH CONDITIONS: A STRUCTURED LITERATURE REVIEW
}

\author{
Larysa Zasiekina \\ lora.zasyekina@gmail.com \\ Anglia Ruskin University, UK
}

Received December 3, 2018; Revised December 8, 2018; Accepted December 14, 2018

\begin{abstract}
Expressed Emotion (EE) is a well-validated measure of the family environment of individuals with mental and physical conditions that examines relatives' critical, hostile and emotionally overinvolved attitudes towards a family member with a condition. This review focuses on studies of EE on containing data of the impact of Expressed Emotion on the course of chronic illnesses and clinical outcomes in mental and physical health conditions. The structural literature review is based on the search of articles in peer-reviewed journals from 1991 to November, 2018 in the databases Psyc-Info and PubMed. Taken together, these results suggest that there is an association between EE towards patients with both physical and mental conditions and a poor clinical and personal recovery. Interestingly, the lower levels of EE towards individuals with a condition were observed in partners comparatively with parents, adult children and relatives. However, the results have been obtained only from two populations with dementia and Type I diabetes and have been considered as important issue for future research.
\end{abstract}

Keywords: Expressed Emotion, mental and physical conditions, critical, hostile and emotionally overinvolved attitudes, caregivers, service users.

Засскіна Лариса. Експресивна емоція як ставлення до осіб із психічними і фізикними захворюваннями: структурний огляд літератури.

Анотація. Експресивна емоція - це термін на позначення ставлення членів родини до особи, яка має проблеми психічного або фізичного здоров'я. Експресивна емоція визначається через вираження критичності, ворожості та гіперопіки з боку члена сім'ї до особи 3 проблемами здоров'я, що негативно впливає на перебіг ії захворювання та процес одужання. Запропоноване структуроване інтерв'ю відображає критичний огляд досліджень з проблеми експресивної емоції упродовж 1991-2018рp. та грунтується на публікаціях в базах Psyc-Info, PubMed. Результати теоретичного аналізу літератури, свідчать що експресивна емоція часто $\epsilon$ одним із важливих чинників погіршення фізичного чи психічного станів пацієнтів. Примітно, що найнижчий рівень експресивної емоції спостерігається у партнерів подружжя порівняно 3 іншими дорослими членами родини: дітьми, батьками, найближчими родичами. Водночас отримані результати встановлено лише в родинах пацієнтів 3 діагнозами деменція та діабет першого ступеня. Це зумовлює необхідність подальшого вивчення експресивної емоції 3 пацієнтами різних груп фізичних і психічних захворювань.

Ключові слова: експресивна емочія, психічні і фізичні захворювання, критичні, ворожі ставлення, гіперопіка, доглядач, пачієнти.

\section{Introduction}

\subsection{Expressed emotion}

Expressed Emotion (EE) is a well-validated measure of the family environment of individuals with mental and physical conditions that examines relatives' critical,

\footnotetext{
(C) Zasiekina, Larysa, 2018. This is an Open Access article distributed under the terms and conditions of the Creative Commons Attribution 4.0 International Licence (http://creativecommons.org/licenses/by/4.0).

East European Journal of Psycholinguistics, 5(2), 108-117. https://doi.org/10.5281/zenodo.2583670
} 
hostile and emotionally overinvolved attitudes towards a family member with a condition (Cherry, Taylor, Brown, \& Sellwood, 2018). The EE is in line with the bio-psycho-social model which was conceptualized by Engel (1977), focusing on clinical and personal recovery of service users from medical (clinical symptoms), psychological (thoughts, emotions, behaviours) and social (family relationships) perspectives.

The first conceptualization of EE was based on an assessment of family relationships represented by five types of attitudes towards the individual with schizophrenia: critical remarks, hostility, dissatisfaction, warmth and emotional over-involvement (Brown, Birley, \& Wing, 1972). The Camberwell Family Interview (CFI) was considered as the gold standard for EE assessment (Hooley \& Parker, 2006).

In present studies there is a tendency to use only the negatively valued EE of criticism, hostility, and emotional over-involvement, since these types of EE appear to be closely linked with the course of chronic illness (Hooley \& Parker, 2006). Much of the current literature on EE measurement pays particular attention to the Five Minutes Speech Sample (FMSS), Standardized Clinical Family Interview (SCFI); Level of EE questionnaire (LEEQ); EE Family Questionnaire (EEFQ). The presented tools are appropriate, easy in use and have high predictive validity for EE overall level, criticism and emotional over-involvement both in mental and physical health conditions.

Existing researches recognise the critical role played by EE in the poor prognosis of mental illnesses and their early relapses (Brown et al., 1972). However, evidence consistently suggests that $\mathrm{EE}$ is a highly reliable and valid predictor of poor clinical outcome in individuals not only with mental, but also with physical conditions (Wearden, Tarrier, Barrowclough, Zastowny, \& Rahill, 2000).

\subsection{Expressed emotion and mental illnesses}

Data from several sources has identified the high level of EE associated with poor outcomes and early relapses of mental illnesses, mainly schizophrenia, eating disorders, depression and anxiety, chronic pain, obsessive-compulsive disorders, autism spectrum disorder, Alzheimer's disease and dementia (Ayilara, Ogunwale, \& Babalola, 2017; Wearden, Tarrier, Barrowclough et al., 2000).

$\mathrm{EE}$ in mental health conditions appears to be positively related to poor relationships of carers with the service users, mostly carers' high criticism as a result of the psychological distress and burden (Coomber \& King, 2013).

As noted by Safari, Berry, and Wearden (2018) EE in mental health conditions is far more predictive depending on the type of illnesses and the status of the family member. The level of EE is higher in adult children or relatives rather than spouses towards the individuals with dementia (Safari et al., 2018; Wearden, Tarrier, Barrowclough et al., 2000). Data from several studies suggest that carers express more critical than emotionally over-involving attitudes towards the individuals with dementia and Alzheimer's disease; and the lower level of EE towards the population with autism spectrum disorder than in the samples with other 
mental illnesses (Romero-Gonzalez, Chandler, \& Simonoff, 2018; Safari et al., 2018; Wearden, Tarrier, Barrowc lough et al., 2000).

\subsection{Expressed emotion and physical health conditions}

Notwithstanding the many pieces of evidence for the poor impact of EE on the prognosis of the mental illnesses, very little is currently known about EE in connection with physical health conditions. The recent systematic literature review shows that several attempts have been made to examine the impact of EE on the medical conditions of diabetes, asthma, rheumatoid arthritis, heart surgery and obesity (Wearden, Tarrier, Barrowclough et al., 2000).

Several reports have shown that EE towards individuals with physical health conditions is not so widespread compared with individuals with mental illnesses (Wearden, Tarrier, Barrowclough et al., 2000). Evidence suggests the rate of carers with a high level of EE in Type 1 diabetes population is $17 \%$, compared with $41.4 \%$ of carers with a high level of EE towards the individuals with schizophrenia and $28 \%$ of carers towards the population with dementia is $28 \%$ (Safari et al., 2018; Wearden, Tarrier, \& Davies, 2000). There is no general agreement also about the association of EE and outcomes of the illnesses in the cases of rheumatoid arthritis, heart surgery and obesity. However, the presented data provides evidence for the association of the critical attitude of carers and the frequency of asthma and epileptic attacks in the service users (Wearden, Tarrier, Barrowclough at al., 2000).

To date there has been little agreement on what can be taken as positive or negative clinical outcomes of the physical illness. The recent systematic literature review concludes that the self-management and health-related quality of life can be taken as positive outcomes of the physical conditions and EE could have a strong impact on it (Wearden, Tarrier, Barrowclough et al., 2000).

\subsection{Objective}

This study therefore sets out to review articles containing data of the impact of $\mathrm{EE}$ on the course of chronic illnesses and to compare this impact on clinical outcomes in mental and physical health conditions.

\section{Methods}

\subsection{Selection the corpus of literature}

This study uses a descriptive approach to examine EE in both physical and mental health conditions. The structural literature review was based on the search of articles in peer-reviewed journals from 1991 to November, 2018. The databases Psyc-Info and PubMed were searched using inclusion criteria for the articles.

- Articles should represent bio-psycho-social methodology with the holistic and etiological principles for explaining the construct of EE under mental and physical health conditions and its impact on clinical outcomes.

- Articles should represent a classical view of EE or recent data (last three years) of EE in physical and mental health conditions.

- The assessment of EE presented in the articles was carried out either by CFI, FMSS, SCFI, LEEQ, EEFQ. 
- Articles should be published in peer-reviewed journals.

This review follows a literature search with in-depth analysis of the key words and phrases: EE, EE in medical / mental conditions', caregivers'/cares'/significant others' / family members' EE.

The initial corpus contained 33 articles, after the selection procedure based on the inclusion criteria 10 articles were chosen. Most articles excluded from the research did not have up to date information or had other than CFI; FMSS SCFI; LEEQ; EEFQ.methods for assessment.

\subsection{Summarizing results}

The results of the search based on inclusion criteria are summarized in Appendix.

\section{Discussion of literature search}

\subsection{The convergences of $E E$ in mental and physical health conditions}

The results of the literature search show, on the one hand, the expansion of the EE content, referring not only to the psychiatric, but also physical conditions. The expansion of the content of $\mathrm{EE}$ is carried out, firstly, through its applications in various clinical settings: schizophrenia, eating disorders, depression and anxiety, Alzheimer's disease and dementia, diabetes, asthma, rheumatoid arthritis, heart surgery and obesity (Wearden, Tarrier, Barrowclough et al., 2000). Secondly, following the bio-psycho-social methodology, enriching of the EE content has been made through its association with important individual and social constructs: selfesteem, meaningful style of life, stigma, family EE profiles (Chan \& Mak, 2017; .Rienecke, Lebow, Lock, \& Le Grange, 2015). Moreover, the positive correlation was found between EE and avoidance attachment and poor mentalisation in carers of the individuals with chronic illness (Cherry et al., 2018). Recent study also suggests that EE profiles exist in the families with individuals with mental and physical conditions; containing four various combinations of low / high level of EE in service users and their cares (Rienecke et al., 2015).

On the other hand, the narrowing of the EE content can be observed, mostly connected with reducing the number of EE types: from five types in CFI (critical remarks, hostility, dissatisfaction, warmth and emotional over-involvement) to three types in other EE assessment tools (criticism, emotional over-involvement, overall level of EE) (Wearden, Tarrier, Barrowclough et al., 2000).

Notwithstand ing many advantages of CFI and considering it as a gold standard for EE assessment, FMSS is more often applied in recent researches of individuals with mental and physical conditions. FMSS takes only five minutes for administrating vs. 20 minutes in CFI, which is more appropriate and convenient both for experimenter and respondents. Moreover, FMSS has a strong validity and predictive value in the high level of $\mathrm{EE}$, both in mental and physical health conditions (Wearden, Tarrier, Barrowclough et al., 2000).

There is a large body of literature that is concerned with the poor impact of a high level of EE for the course and outcomes of the chronic illness (Ayilara et al., 2017; Romero-Gonzalez et al., 2018; Safavi et al., 2018; Wearden, Tarrier, 
Barrowclough et al., 2000). Particular attention is paid, both to the clinical recovery as reducing medical symptoms of the disease and preserving the good prognosis for its course; and personal recovery as having the meaningful style of life, selfefficiency and self-management by individuals with the chronic illness (Chan \& Mak, 2017).

The role of EE in personal recovery under both mental and physical conditions shares the key features, since it refers mostly to the diseases of a chronic nature. In this case the individuals cannot expect full recovery; however, they can hope for stable health conditions, health related quality of life and efficient self-management (Wearden, Tarrier, Barrowclough et al., 2000). Therefore the family support and reducing the high level of $\mathrm{EE}$ is of primary importance for a positive prognosis and outcomes of both mental and physical illnesses.

The impact of the status of family member on EE towards the individuals is similar in physical and mental health conditions. Wearden, Tarrier, and Davies . (2000) found dramatic differences in the rate of carers with high levels of EE between partners and relatives of individuals with Type I diabetes, correspondently $10 \%$ and $37 \%$. Similar results were found in the condition of dementia. The higher level of EE was revealed in adult children and relatives rather than spouses, correspondently $40 \%$ and $22 \%$ (Safavi et al., 2018). High level of EE is particularly frequently observed in mothers of individuals with schizophrenia (Bogojevic, Ziravac, \& Zigmund, 2015).

\subsection{The divergences of $E E$ in mental and physical health conditions}

In contrast to earlier findings of $\mathrm{EE}$ in mental conditions, however, no evidence of EE towards individuals with physical conditions was detected for several decades. The most obvious findings to emerge from the analysis is that EE towards individuals with physical conditions is different from EE in mental clinical settings. One unanticipated finding was that $\mathrm{EE}$ in physical conditions is less spread than EE in mental health conditions. Recent evidence suggests that $25 \%$ of husbands have demonstrated a high level EE towards their women struggling with rheumatoid arthritis and heart surgery as compared with rates of husbands with a high level of EE towards schizophrenia and bipolar affective disorder, correspondently $41 \%$ and $37 \%$ (Ayilara et al., 2017; Wearden, Tarrier, Barrowclough et al., 2000).

The lower percentage of a high level of EE in physical health rather than in psychiatric health conditions may be explained by the fact that the critical remarks in the physical clinical settings mostly refer to the symptoms of disease while in mental clinical settings to the personal traits and behavioural patterns of the individuals with the condition. There is, however, another possible explanation connected with the stigma towards psychiatric disorders which can play the mediating role in the development of the high level of EE in the caregivers (Chan \& Mak, 2017).

In contrast to the findings in the population with mental health conditions, there is evidence for the positive impact of the carers' $\mathrm{EE}$ on clinical outcomes in the case of Type I diabetes (Wearden, Tarrier, \& Davies, 2000). Areas where significant differences have been found include emotional over-involvement in 
mental and medical conditions. In contrast to earlier findings in the cases of schizophrenia, carers' emotional over-involvement towards ind ividuals with Type I diabetes is associated with better glucose control. Notwithstanding the positive impact of emotional over-involvement of individuals with Type I diabetes on glucose control, the relation of emotional over-involvement with efficient selfmanagement and psychological adaptation to the diabetes conditions is still unclear (Wearden, Tarrier, \& Davies, 2000). However to determine the effects of EE on health related quality of life of individuals with physical conditions, researches argue that service users with adherence to the diet are the most sensitive to EE (Flanagan \& Wagner, 1991 ).

There are a number of important differences between EE in physical and mental conditions in terms of the EE impact on clinical outcomes. The high level of EE towards individuals with schizophrenia and dementia is associated with early relapses of the illnesses (Bogojevic et al., 2015). The poor impact of the high level of EE towards individuals with physical conditions is associated with poor selfmanagement and poor adherence to the diet (Wearden, Tarrier, Barrowclough et al., 2000).

The critical remarks towards EE in both physical and mental conditions share a number of key features. Much of the current literature on the high level of EE in mental conditions connect them with worsening the course of the illness in terms of reinforcing negative core beliefs, early relapses and poor prognosis of the outcomes. Whereas in the cases of some physical conditions, notably in asthma and epilepsy, the high level of EE is associated with more frequent attacks than low level of EE. The high criticism was observed in a larger population of mothers of children with frequent asthma attacks in comparison with the population of mothers with low frequency of the attacks, correspondently $6 / 7$ and 4/18. These results are similar to those reported in the population of mothers with frequent and infrequent epilepsy attacks, correspondently 12/14 and 20/18 (Wearden, Tarrier, Barrowclough et al., 2000).

\section{Limitations and Methodological Issues}

First, the selection of the article on the topic of EE was based either on the classical bio-psycho-social methodology of EE study, or on the recent data during the last three years. Therefore many articles highlighted EE in psychiatric conditions were excluded from the analysis. Secondly, the increasing interests to EE towards individuals with physical health conditions determine the development of many new $\mathrm{EE}$ assessment tools. However, some of them require examining their reliability and predictive value. Therefore the artic les with data obtained by other than CFI; FMSS SCFI; LEEQ; EEFQ were excluded from the research.

\section{Conclusion}

The aim of the present literature review was to examine the development of the construct of $\mathrm{EE}$ in recent studies and compare the carers' $\mathrm{EE}$ towards individuals with mental and physical conditions. This study has shown that the content of EE in 
recent studies is applied to a broad context including mental and physical conditions. EE is closely connected not only with clinical symptoms of the illnesses but also with personal recovery.

This study has found that generally EE towards patients with both physical and mental conditions has a poor impact on clinical and personal recovery. The level of $\mathrm{EE}$ is associated with the status of the carers, both in physical and mental conditions. The partners demonstrate considerably lower levels of EE towards individuals with a condition than parents, adult children and relatives. However, the results have been obtained only from two populations with dementia and Type I diabetes. Therefore this is an important issue for future research.

Regarding the poor impact of EE on individuals with a physical condition, the service users with adherence to the diet are the most sensitive to EE. Firstly, a chronic course of dietary adherence is connected with the mental comorbidities of services users and the psychological burden of their carers. Secondly, individuals with these diseases must adhere to a life-long strict diet to control their symptoms and prevent short- and long-term problems. EE research has shown to have a predictive value not only for these service users' outcomes, but also for treatment compliance. However, little is known about the different impact of emotional overinvolvement and criticism on health related quality of life and dietary adherence in individuals with physical diseases. A further study with more focus on the impact of EE on the quality of life and dietary adherence in individuals with physical health conditions is therefore suggested.

\section{References}

Ayilara, O., Ogunwale, A., \& Babalola, E. (2017). Perceived expressed emotion in relatives of patients with severe mental illness: A comparative study. Psychiatry research, 257, 137-143.

Bogojevic, G., Ziravac, L., \& Zigmund, D. (2015). Impact of expressed emotion on the course of schizophrenia. European Psychiatry, 30, 390.

Brown, G. W., Birley, J. L. T., \& Wing, J. K. (1972). Influence of family life on the course of schizophrenic disorders: A replication. British Journal of Psychiatry, 121, 241-258.

Chan, K. K., \& Mak, W. W. (2017). The content and process of self-stigma in people with mental illness. American Journal of Orthopsychiatry, 87(1), 34-43.

Cherry, M. G., Taylor, P. J., Brown, S. L., \& Sellwood, W. (2018). Attachment, mentalisation and expressed emotion in carers of people with long-term mental health difficulties. BMC Psychiatry, 18(1), 257.

Coomber, K., \& King, R. M. (2013). Perceptions of carer burden: differences between individuals with an eating disorder and their carer. Eating Disorders, 21 (1), 26-36

Engel, G. L. (1977). The need for a new medical model: a challenge for biomedicine. Science, 196(4286), 129-136.

Flanagan, D. A., \& Wagner, H. L. (1991). Expressed emotion and panic fear in the prediction of diet treatment compliance. British Journal of Clinical Psychology, 30, 231-240.

Hooley, J. M., \& Parker, H. A. (2006). Measuring expressed emotion: An evaluation of the shortcuts. Journal of Family Psychology, 20(3), 386.

Rienecke, R. D., Lebow, J., Lock, J., \& Le Grange, D. (2015). Family profiles of expressed emotion in adolescent patients with anorexia nervosa and their parents. Journal of Clinical Child \& Adolescent Psychology, 46(3), 428-436. 
Romero-Gonzalez, M., Chandler, S., \& Simonoff, E. (2018). The relationship of parental expressed emotion to co-occurring psychopathology in individuals with autism spectrum disorder: A systematic review. Research in developmental disabilities, 72, 152-165.

Safavi, R., Berry, K., \& Wearden, A. (2018). Expressed emotion, burden, and distress in significant others of people with dementia. Journal of Family Psychology, 32(6), 835.

Wearden, A. J., Tarrier, N., Barrowclough, C., Zastowny, T. R., \& Rahill, A. A. (2000). A review of expressed emotion research in health care. Clinical Psychology Review, 20(5), 633-666.

Wearden, A. J., Tarrier, N., \& Davies, R. (2000). Partners' expressed emotion and the control and management of Type 1 diabetes in adults. Journal of Psychosomatic Research, 49(2), 125 130.

\section{Appendix}

Table 1

Studies of EE towards Individuals with Mental and Physical Health Conditions

\begin{tabular}{|c|c|c|c|c|}
\hline Authors & $\begin{array}{l}\text { Measurement } \\
\text { tool }\end{array}$ & Aim of study & Types of EE & Obtained results \\
\hline $\begin{array}{l}\text { Flanagan et al. } \\
\text { (1991) }\end{array}$ & CFI & $\begin{array}{l}\text { Assessment of } \\
\text { EE impact on } \\
\text { treatment } \\
\text { compliance in } \\
\text { the population } \\
\text { with obesity }\end{array}$ & $\begin{array}{l}\text { Criticism, hostility, } \\
\text { emotional } \\
\text { involvement }\end{array}$ & $\begin{array}{l}\text { The high level of EE } \\
\text { predicts the poor diet } \\
\text { adherence }\end{array}$ \\
\hline $\begin{array}{l}\text { Wearden, } \\
\text { Tarrier, } \\
\text { Davies et al. } \\
(2000)\end{array}$ & CFI & $\begin{array}{l}\text { Assessment of } \\
\text { EE impact on } \\
\text { management of } \\
\text { Type I diabetes }\end{array}$ & $\begin{array}{l}\text { Criticism, hostility, } \\
\text { emotional over- } \\
\text { involvement, } \\
\text { warmth, positive } \\
\text { remarks towards } \\
\text { individuals with } \\
\text { Type I diabetes }\end{array}$ & $\begin{array}{l}\text { Positive impact of } \\
\text { emotional over- } \\
\text { involvement on glucose } \\
\text { control in individuals } \\
\text { with Type I diabetes was } \\
\text { revealed }\end{array}$ \\
\hline $\begin{array}{l}\text { Wearden, } \\
\text { Tarrier, } \\
\text { Barrowclough } \\
\text { et al. (2000) }\end{array}$ & $\begin{array}{l}\text { CFI, } \\
\text { FMSS }\end{array}$ & $\begin{array}{l}\text { Evaluation of EE } \\
\text { towards } \\
\text { individuals with } \\
\text { mental / medical } \\
\text { conditions: } \\
\text { schizophrenia, } \\
\text { eating disorders, } \\
\text { depression and } \\
\text { anxiety, } \\
\text { Alzheimer's } \\
\text { disease } \\
\text { dementia, and } \\
\text { diabetes, asthma, } \\
\text { rheumatoid } \\
\text { arthritis, heart } \\
\text { surgery and } \\
\text { obesity }\end{array}$ & $\begin{array}{l}\text { Criticism, hostility, } \\
\text { dissatisfaction, } \\
\text { warmth and } \\
\text { emotional over- } \\
\text { involvement }\end{array}$ & $\begin{array}{l}\text { EE has a great } \\
\text { predicative value for } \\
\text { poor clinical outcomes } \\
\text { and early relapses in } \\
\text { schizophrenia and } \\
\text { depression. EE negative } \\
\text { impact on frequency of } \\
\text { epilepsy and asthma } \\
\text { attacks was found }\end{array}$ \\
\hline $\begin{array}{l}\text { Bogojevic et } \\
\text { al. } \\
(2015)\end{array}$ & FMSS & $\begin{array}{l}\text { Evaluation of EE } \\
\text { towards } \\
\text { individuals with }\end{array}$ & $\begin{array}{l}\text { Criticism, emotional } \\
\text { over-involvement, } \\
\text { overall level of EE }\end{array}$ & $\begin{array}{l}\text { High level of EE was } \\
\text { revealed in carers of } \\
71.4 \% \text { patients with } \\
\text { worsening clinical }\end{array}$ \\
\hline
\end{tabular}


schizophrenic

disorder

Rienecke et al. SCFI (2015)

Ayilara et al. LEEQ (2017)

Chan \& Mak. LEEQ (2017)

Cherry et al. EEFQ (2018)

Romero- FMSS

Gonzalez et al. (2018)
Examining

family

profiles in the

families with the adolescents with anorexia nervosa

Assessment of EE towards individuals with schizophrenia

and bipolar disorder

Assessment of EE related to the content of selfstigma and clinical and personal recovery of the individuals with psychiatric disorders

Assessment of EE related to attachment and mentalisation of individuals with long-term mental illness

Examining
carers' EE
towards children
with autism
spectrum
disorder

outcomes. High level of $\mathrm{EE}$ is particularly frequently observed in mothers

Criticism, emotional High level of criticism in parent is associated with the high level of criticism of the adolescent with anorexia nervosa

Criticism, emotional There are no significant over-involvement, differences in EE hostility towards individuals with schizophrenia and bipolar disorder.

Criticism, emotional The strong association over-involvement, of $\mathrm{EE}$ and self-stigma hostility was defined. The high level of criticism has a poor impact on clinical and personal recovery (self-esteem, selfefficiency, selfmanagement) of the individuals with psychotic and nonpsychotic disorders

Criticism, emotional Association of high over-involvement, criticism and hostility hostility with attachment avoidance and poor mentalisation in carers of the individuals with chronic mental disease was revealed

Criticism, emotional High level of criticism is over-involvement, associated with the overall level of EE growth of behavioural problems of adolescents with autism spectrum disorder. There is a higher rate of mothers with high $\mathrm{EE}$ level towards children with schizophrenia than towards children with autism spectrum disorder, $48.6 \%$ and $15.5 \%$; higher percentage of mothers 
with high EE level towards children with intellectual disability than towards children with autis $m, 66.0 \%$ and 9.6-28.7\%

Safavi et al. CFI (2018)
Examining relation EE high level to burden and distress in carers individual with dementia
Criticism, hostility, High level of $\mathrm{EE}$ is dissatisfaction, warmth emotional involvement associated with the burden and distress in over- the carers of individuals with dementia both in the beginning of the study and in the control stage in 6 months 